\title{
Małgorzata Rajtar
}

malraj@amu.edu.pl

Instytut Etnologii i Antropologii Kulturowej

Uniwersytet im. Adama Mickiewicza w Poznaniu

\section{O (NIE)NATURALNOŚCI JEDZENIA. POKARMY I TECHNOLOGIE BIOMEDYCZNE W CHOROBACH METABOLICZNYCH}

\author{
On the (Un)Naturalness of Eating: \\ Foods and Biomedical Technologies in Metabolic Disorders
}

\begin{abstract}
Streszczenie: W obrazie wykreowanym przez media i opinię publiczną karmienie przez rurkę nieodłącznie związane jest z osobami starszymi i/lub umierającymi. Także w literaturze z zakresu antropologii medycznej ta technologia biomedyczna pojawia się często w kontekście „nowych definicji życia i śmierci", co prowadzi do zamazywania innych znaczeń towarzyszących karmieniu przez rurkę i/lub PEG-a. Wykorzystując badania prowadzone od 2016 roku wśród pacjentów z niedoborem LCHAD, rzadką chorobą metaboliczną, w której specjalna dieta odgrywa kluczową rolę, ich rodziców, lekarzy i przedstawicieli organizacji pacjenckich w Polsce i w Finlandii, w niniejszym artykule analizuję doświadczenia pacjentów, którzy byli lub nadal są karmieni przez sondę, zajmujących się nimi członków rodzin i dietetyków. Z uwagi na konieczność przestrzegania diety, pacjenci z niedoborem LCHAD postrzegani są często jako osoby, których „stosunek do jedzenia” odbiega od „normy”: jedzą zbyt często albo wręcz odwrotnie - nie jedzą. Argumentuję, że podejście biomedyczne, które kładzie nacisk na dostarczanie ciałom pacjentów odpowiedniej ilości składników odżywczych w procesie karmienia przez rurkę nie uwzględnia, jak pokazują studia antropologiczne, faktu, że jedzenie pełni też rolę w budowaniu relacji społeczno-kulturowych. Ponadto pokazuję, że w tym wypadku technologia biomedyczna może przyczynić się do kwestionowania „naturalności” jedzenia.
\end{abstract}

Słowa kluczowe: antropologia medyczna; choroby rzadkie; LCHAD; jedzenie; karmienie przez rurkę; gastrostomia; technologie biomedyczne.

Abstract: Tube feeding, both in its media portrayals and in the public view is usually associated
with the elderly and/or the dying. Medical anthropology scholarship has often attended to this bio-
medical technology in the context of "new definitions of death and life" that blurs other meanings
associated with tube feeding and/or PEG. This article examines LCHAD deficiency, a rare meta-
bolic disease that is treated with a special diet. Since 2016, my research has focused on patients,
their parents, physicians, and members of patient advocacy groups in Poland and Finland. I ad-
dress experiences of patients who have been tube fed, their family caregivers, and dietitians. Due to
dietary recommendations, patients with LCHAD deficiency are often perceived to have an "attitude 
towards eating" that is far from "normal." They either eat too often or do not eat at all. The biomedical approach aims at providing sufficient nutrition to patients' bodies via the feeding tube. I argue that it does not, however, account for eating as a process of building socio-cultural relations that have been analyzed in anthropological scholarship. Moreover, I show that biomedical technology may contribute to questioning the "naturalness" of eating in this case.

Keywords: medical anthropology; rare diseases; LCHAD; food; eating; feeding tube; gastrostomy; biomedical technologies.

\section{Wprowadzenie}

Na krótko przed Feeding Tube Awareness Week organizowanym w lutym 2014 roku, Traci Nagy, założycielka Feeding Tube Awareness Foundation (w 2010 roku) i matka chłopca karmionego przez rurkę ${ }^{1}$, podzieliła się z czytelnikami bloga „Food for Thought" (b.d.) swoimi pierwszymi doświadczeniami związanymi z karmieniem przez sondę. Syn pani Nagy, u którego zdiagnozowano Koolen de Vries Syndrome (KdVS, także zespół mikrodelecji 17q21.31), rzadką chorobę genetyczną, swoją pierwszą sondę otrzymał w wieku dwóch miesięcy w 2008 roku. Zgodnie z obrazem kształtowanym wówczas przez media, rurka kojarzyła się pani Nagy z osobami starszymi i umierającymi. Pisała:

Kiedy zaczynasz proces karmienia przez rurkę, doświadczenie osamotnienia jest ewidentne. To znacznie więcej niż ogromny niepokój, który wiąże się z zawiłościami medycznymi i z tym, że nie znasz nikogo, kto kiedykolwiek karmił przez rurkę. Poprzez jedzenie świętujemy, okazujemy miłość, budujemy więź z dzieckiem i dzielimy szczególne chwile z przyjaciółmi i rodziną. Jedzenie jest kluczowe dla naszej tożsamości [being], ludziom trudno jest zrozumieć przyczyny, dla których ktoś nie może jeść, przyczyny, które nie są śmiertelne. [...] Moje doświadczenia z synem były zupełnie przeciwstawne do negatywnego obrazu kształtowanego przez media i moich własnych, wczesnych przekonań związanych z karmieniem przez rurkę (Food for Thought b.d.).

„Negatywny obraz kształtowany przez media”, o którym wspomina pani Nagy, odnosił się do słynnego przypadku Thierry Schiavo, o którym pisano, że „żaden inny w Stanach Zjednoczonych nie wywołał takiej aktywności politycznej i prawnej" (Bishop 2011: 201). U Th. Schiavo, podobnie jak w równie słynnym przypadku Eluany Englaro we Włoszech, został zdiagnozowany „utrwalony stan wegetatywny” - jako

\footnotetext{
${ }^{1} \mathrm{~W}$ niniejszym tekście stosuję wymiennie określenia „karmienie przez rurkę" lub „karmienie przez sondę", mając na myśli karmienie przez sondę nosowo-żołądkową i gastrostomię odżywczą/PEG-a. Podobne określenia używane są na stronach ww. Fundacji oraz w rozmowach z badanymi.
} 
rezultat trwałego uszkodzenia mózgu w wyniku zatrzymania krążenia w 1990 roku u pierwszej i uszkodzenia mózgu w wypadku samochodowym w 1999 roku u drugiej. Obydwie karmione były przez przezskórną endoskopową gastrostomię (PEG, ang. percutaneous endoscopic gastrostomy) przez odpowiednio piętnaście (do 2005 roku) i siedemnaście lat (do 2009 roku). Zaprzestanie karmienia przez rurkę w obydwu przypadkach odbyło się decyzją sądu i w atmosferze politycznej i religijnej mobilizacji opinii publicznej; krótko później kobiety zmarły (Bishop 2011).

Jak pokazują przykłady Th. Schiavo i E. Englaro, dla mediów i opinii publicznej karmienie przez sondę może kojarzyć się w pierwszej kolejności ze śmiercią i umieraniem. Jednak doświadczenia, które opisywała pani Nagy i które skłoniły ją do założenia Fundacji sugerują, że możliwe są tu także inne interpretacje. W niniejszym tekście pragnę zatem wysunąć na pierwszy plan kwestie jedzenia i niejedzenia, które są nierozłącznie związane z karmieniem przez rurkę. Jedzenie, nie tylko zresztą w Stanach Zjednoczonych, „nigdy nie jest "tylko« jedzeniem” (Allison 2007: 149), na co wskazywali antropologowie społeczni(Douglas 2007, Mintz 1985), antropologowie medyczni(Helman 2007: 52-80), czy antropologowie religii (Boylson 2013). Karmienie przez rurkę pozwala jednak w szczególny sposób sproblematyzować kwestię (nie)jedzenia i postawić pytanie, czy jedzenie jest czynnością tak oczywistą i „naturalną”, jak mogłoby nam się wydawać. Takie odczytywanie splotu technologii biomedycznych, kwestii jedzenia i odżywiania w kontekście chorób rzadkich jest nieczęsto podejmowane przez antropologów społecznych i medycznych. Parafrazując Marcela Maussa (Mauss 2001), można spojrzeć na jedzenie jako na „sposób posługiwania się ciałem”, zapośredniczony w niektórych wypadkach przez technologię biomedyczną.

$\mathrm{Na}$ liście Feeding Tube Awareness Foundation (b.d.), której celem jest wspieranie rodziców dzieci karmionych przez rurkę poprzez „podnoszenie pozytywnej świadomości dotyczącej tego, czym jest karmienie przez rurkę jako interwencja medyczna ratująca życie", znajduje się około dwustu chorób, które mogą wiązać się z koniecznością karmienia dzieci przez sondę, w tym niedobór LCHAD (ang. Long-Chain 3-Hydroxyacyl-CoA Dehydrogenase deficiency; pol. niedobór dehydrogenazy długołańcuchowych kwasów tłuszczowych), główny bohater tego tekstu. Zresztą sama historia założenia Fundacji i cele, jakie sobie stawia, doskonale wpisują się we wprowadzoną przez Paula Rabinowa (Rabinow 1996) koncepcję „biouspołecznienia" (biosociality). Jak podkreślał P. Rabinow, nowa genetyka, której narzędziem są między innymi badania przesiewowe noworodków, doprowadzi do „tworzenia 
nowych tożsamości i praktyk grupowych i jednostkowych [...]. Grupy te będą miały specjalistów medycznych, laboratoria, narracje, tradycje i szeroki wachlarz opiekunów, którzy pomogą im doświadczać, dzielić się, interweniować i "rozumieć« swój los" (Rabinow 1996: 102; zob. Gibbon, Novas 2008).

Niniejszy artykuł rozpoczynam od charakterystyki niedoboru LCHAD i wymagań dietetycznych, które ściśle wiążą się z „leczeniem” tej choroby rzadkiej oraz wskazań biomedycznych do karmienia rurką. Opierając się na badaniach prowadzonych od 2016 roku wśród pacjentów z niedoborem LCHAD, ich rodziców, lekarzy i przedstawicieli organizacji pacjenckich w Polsce i w Finlandii ${ }^{2}$, dalszej części tekstu przejdę do analizy doświadczeń tych pacjentów, którzy byli lub nadal są karmieni przez sondę, zajmujących się nimi członków rodzin i dietetyków. Poruszę także kwestię, którą chciałabym na potrzeby tego tekstu nazwać „(nie)naturalnością jedzenia" i związków między technologią biomedyczną i jedzeniem.

\section{Rzadkie choroby metaboliczne na przykładzie niedoboru LCHAD}

Opisany po raz pierwszy w 1989 roku niedobór LCHAD jest to rzadka, zagrażająca życiu, uwarunkowana genetycznie choroba metaboliczna ${ }^{3}$, która może prowadzić do nagłej śmierci noworodka, ciężkiej niepełnosprawności i ślepoty (Immonen 2016; Piekutowska-Abramczuk i in. 2010; Sykut-Cegielska 2006). Terminem „choroby rzadkie” określa się dużą grupę chorób (7000-8000), które dotykają w Unii Europejskiej nie więcej niż

\footnotetext{
${ }^{2}$ Badania prowadzone są w ramach kierowanego przeze mnie grantu pt. „Społeczno-kulturowe wymiary chorób rzadkich na przykładzie niedoboru LCHAD. Studium porównawcze Polski i Finlandii" finansowanego przez Narodowe Centrum Nauki (Nr grantu UMO-2015/17/B/HS3/00107), w którym oprócz mnie biorą udział dwie badaczki: dr hab. Anna Kwaśniewska, prof. UG oraz mgr Anna Chowaniec-Rylke, doktorantka na UW. W niniejszym tekście wykorzystuję przede wszystkim wyniki badań prowadzonych w Polsce. Z uwagi na fakt, że piszę tutaj o rzadkiej chorobie, liczba pacjentów z niedoborem LCHAD jest stosunkowo niewielka, zatem wszystkie imiona, nazwiska i przezwiska, którymi posługuję się w tekście są pseudonimami. Konieczność zachowania i ochrony anonimowości badanych nakazuje także zmianę nazw miejscowości, z których pochodzą i niepodawanie dokładnego wieku rozmówców.

${ }^{3} \mathrm{~W}$ polskim piśmiennictwie biomedycznym oraz w trakcie organizowanych dla pacjentów i ich rodzin spotkań, takich jak „Akademia Metaboliczna” w Sękocinie pod Warszawą w listopadzie 2016 roku, często używa się terminu „wrodzone wady metabolizmu”. Termin ten ukuł w 1909 roku Archibald Garrod po to, aby scharakteryzować „grupę schorzeń, które "najwyraźniej wynikają z niewydolności [failure] takiego czy innego etapu w serii zmian chemicznych, które składają się na metabolizm«" (Paul, Brosco 2013: 11) Jak pisze socjolożka nauki, Hannah Landecker (Landecker 2013), koncepcja "metabolizmu” została ugruntowana w XIX wieku w rezultacie wspólnych wysiłków z zakresu chemii i fizjologii zwierząt. Badaczka podkreśla, że „wrodzone wady metabolizmu” postrzegano jako choroby „ciał przemysłowych” (Landecker 2013: 496).
} 
5 na 10000 osób; w Stanach Zjednoczonych nie więcej niż 7,5 na 10 000, a w Japonii nie więcej niż 4 na 10000 (Huyard 2009). Szacuje się, że choroby rzadkie dotykają od 6 do $8 \%$ populacji. Często są to poważne, przewlekłe choroby, które prowadzą do kalectwa, a nawet śmierci. Choroby te stanowią wyzwanie nie tylko dla pacjentów i ich rodzin, lecz także dla systemu opieki zdrowotnej (Libura i in. 2016). Część z tych chorób diagnozowana jest w ramach przesiewowych badań noworodków (zob. Paul i Brosco 2013; Timmermans i Buchbinder 2013). Niedobór LCHAD włączono do tych badań w Finlandii i w całej Polsce odpowiednio w 2015 i w 2013 roku. W przypadku braku diagnozy i podjęcia leczenia choroba charakteryzuje się wysoką śmiertelnością. Choroba występuje niezwykle rzadko w Australii i Ameryce Północnej, jednak dosyć często w Europie - szczególnie w regionie Morza Bałtyckiego, w krajach takich jak Finlandia (Immonen 2016) i Polska (Piekutowska-Abramczuk i in. 2010).

Między 1976 a 2014 rokiem niedobór LCHAD zdiagnozowano u czterdziestu siedmiu pacjentów w Finlandii, z których dwudziestu siedmiu zmarło (Immonen 2016). W Polsce zdiagnozowano tę chorobę u pięćdziesięciu dziewięciu pacjentów pomiędzy 1986 a 2009 rokiem, z których zmarło dwudziestu (Piekutowska-Abramczuk i in. 2010; Sykut-Cegielska i in. 2011).

Podobnie jak w wypadku wielu innych chorób rzadkich, na niedobór LCHAD nie ma na razie lekarstwa (zob. Larotonda 2016). Obok unikania „głodzenia” i nadmiernego wysiłku fizycznego, uboga w tłuszcze i bogata w węglowodany dieta jest jedynym sposobem terapii. W praktyce oznacza to, że osoby cierpiące na tę chorobę powinny spożywać posiłki co 3-4 godziny w ciągu dnia (w zależności od wieku) i unikać nocnego „głodzenia". Lista pokarmów zabronionych jest dosyć długa i obejmuje między innymi wszystkie oleje i tłuszcze, tłuste mięso i wędliny, ale również majonez, żółtka, sery i produkty mleczne, w których zawartość tłuszczu wynosi powyżej 0-0,5\%, czekoladę, niektóre owoce i warzywa (tj. awokado, oliwki) i orzechy. W miejsce „niepożądanych” tłuszczów, które zawierają długołańcuchowe kwasy tłuszczowe, pacjentom suplementowany jest olej MCT (Medium-chain trigliceryde), który zawiera średniołańcuchowe kwasy tłuszczowe 4 . Ponadto noworodki, u których zdiagnozowano niedobór LCHAD, nie powinny, według niektórych rozmówców, spożywać mleka matki, lecz mieszanki

\footnotetext{
${ }^{4}$ Oprócz oleju MCT, który dostępny jest na tzw. import docelowy, pacjenci spożywają np. MCT Procal (producent: Vitaflo). Suplementy zawierające MCT produkowane są przede wszystkim przez dwie firmy -Nutricia (holenderska firma, która od 2007 roku jest częścią koncernu Danone) oraz Vitaflo (brytyjska firma, która jest obecnie częścią koncernu Nestlé Health Science). Te same firmy często sponsorują niekiedy kilkudniowe spotkania i konferencje pacjentów i ich rodzin oraz lekarzy, dzięki czemu, jak powiedziała mi jedna z lekarek opiekujących się dziećmi z LCHAD, takie spo-
} 
mleczne z MCT (tj. Lipistart ${ }^{\oplus}$ - producent Vitaflo, Monogen ${ }^{\oplus}$ - producent Nutricia lub Humanę z MCT). Dieta pacjentów z LCHAD odbiega więc znacząco od diety rekomendowanej „normalnym” noworodkom i dzieciom (por. Weker i Barańska 2014). Takie same mieszanki podawane są również starszym dzieciom i nastolatkom karmionym przez rurkę. Zdaniem jednej z dietetyczek, z którymi rozmawiałam:

Poza tym, że możemy ją [mieszankę] stosować od urodzenia, to możemy ją stosować, no w zasadzie bardzo długo, do kiedy dziecko chce pić mleko. Jak są dzieci karmione przez gastrostomię odżywczą czy czasowo przez sondę nosowo-żołądkową, bo coś tam się dzieje i trzeba założyć tą sondę, no to oczywiście może być taka mieszanka użyta i u dzieci starszych, i u nastolatków również.

Nieprzestrzeganie zaleceń dietetycznych, ale również przeziębienia, gorączka, biegunka, wymioty, nadmierny stres czy wydatkowanie energii, mogą bardzo łatwo doprowadzić do tzw. dekompensacji metabolicznej ${ }^{5}$ i wymagają natychmiastowej hospitalizacji (Immonen 2016; Sykut-Cegielska 2006).

W życiu codziennym dzieci i nastolatki z niedoborem LCHAD postrzegane są jako osoby, które nieustannie coś jedzą albo wręcz przeciwnie: nie jedzą. Jednym słowem ich relacja do jedzenia nigdy nie jest „normalna” z punktu widzenia rówieśników i osób postronnych (np. nauczycieli). Dobrym przykładem na „nieustanne” jedzenie niech będą doświadczenia jednego z pacjentów w wieku szkolnym. Podczas spotkania organizowanego wiosną 2017 roku przez lekarzy i firmę farmaceutyczną dla dzieci i nastolatków z LCHAD i ich rodziców, któremu obok wykładów dotyczących choroby i diety towarzyszyły także warsztaty kulinarne, rozmawiałam z mamą chłopca w wieku szkolnym. Podkreślała, jak zresztą i inni rodzice chorych dzieci

tkania są bezpłatne dla rodzin. Niestety, z racji ograniczonej objętości niniejszego tekstu pogłębiona analiza tej kwestii jest niemożliwa.

${ }^{5} \mathrm{~W}$ trakcie konferencji i spotkań organizowanych dla chorych i ich rodzin, które dotyczyły wrodzonych wad metabolizmu, terminem „dekompensacja” i/lub „dekompensacja metaboliczna” posługiwano się tak, jakby był on zrozumiały dla wszystkich uczestników oraz bez odwoływania się do definicji biomedycznej. Wskazywano raczej na fakt, że dziecko z LCHAD jest „zagrożone dekompensacją metaboliczną” (np. pod postacią „ciężkiej” hipoglikemii, a więc bardzo niskiego poziomu cukru we krwi). Podkreślano również, że „w przypadku ryzyka wystąpienia dekompensacji metabolicznej (najczęściej w przebiegu infekcji, wymiotów, utraty łaknienia, stanów gorączkowych, po szczepieniach)" lub zwiększonej pracy mięśni konieczna jest natychmiastowa hospitalizacja (notatki z 8.04.2017 r.). W broszurce przeznaczonej dla chorych na acydurie organiczne (rzadka choroba metaboliczna) i ich rodzin, „dekompensację” definiuje się ogólnie jako „termin metaboliczny opisujący początek choroby, w którym dochodzi do załamania metabolizmu i do rozkładu zmagazynowanych białek w komórkach i tkankach. Zazwyczaj jest spowodowany przez biegunkę, wymioty, lekką infekcję" (Gick b.d.: 17). 
w podobnym wieku, że jej syn zdaje sobie sprawę z konieczności częstego spożywania posiłków (i negatywnych konsekwencji w przeciwnym razie) i że regularnie zabiera ze sobą do szkoły mnóstwo przekąsek (kanapek, owoców, soczków), czym zyskał sobie przezwisko. Siedzący tuż obok nas chłopak zaraz dodał, że przezywają go „Banan”, po czym zacy tował przysłowie: „Kto się przezywa, sam się tak nazywa”, dając tym samym jasno do zrozumienia, jaki jest jego stosunek do przezywających go w ten sposób rówieśników. Wykraczanie poza społecznie i kulturowo uznaną normę, niezależnie od tego, czy będzie ona dotyczyła częstotliwości i zawartości posiłków, wyglądu fizycznego itp., stanowi część składową życia z chorobą rzadką. Jak podkreślała Alice Larotonda (Larotonda 2016: 29) w odniesieniu do włoskich dzieci cierpiących na rzadkie choroby, które „wiążą się z namacalnymi zmianami na ciele", czyniąc ich [wygląd] zewnętrzny w sposób znaczący " widocznym«i "innym«", w przyjmowanej przez nie interpretacji tego, co jest „normą” zarówno „zbyt dobry lub zbyt zły wygląd mogą wybiegać poza normalność i stąd mogą być uznawane za problematyczne". W kontekście analizowanych tu doświadczeń chorych z deficytem LCHAD, zarówno zbyt częste jedzenie, jak i niejedzenie wybiegają poza przyjętą społecznie „normę” dotyczącą tego co, jak i kiedy powinno się spożywać.

Konieczność częstego jedzenia, ale również obawa przed „nadmiernym” wydatkowaniem energii i związane z tym ryzyko dekompensacji sprawiają, że część dzieci w wieku szkolnym nie bierze udziału w żadnych aktywnościach pozaszkolnych (np. wycieczkach), co prowadzi do tego, że są lub czują się wykluczone. Zdarza się oczywiście, że niektóre dzieci jeżdżą na wycieczki, chodzą do kina czy teatru wraz z całą klasą, ale tylko dlatego, że towarzyszy im w tych wyprawach jedno z rodziców. Wykluczenie - choć może „zróżnicowanie” byłoby tu lepszym określeniem - choć na nieco innym poziomie ma również miejsce w samych rodzinach. Jako że posiłki dzieci i nastolatków z tą chorobą metaboliczną różnią się, jeśli chodzi o skład, od posiłków spożywanych przez pozostałych członków rodziny (choćby z uwagi na zawartość tłuszczu), matki - które w badanych rodzinach najczęściej gotowały przygotowują dwa posiłki - osobny dla dzieci z niedoborem LCHAD i osobny dla reszty rodziny. Warto jednak zauważyć, że w niektórych rodzinach posiłki dla tych pierwszych „przypominają" te dla tych drugich, o ile nie wykracza to poza zalecenia dietetyczne. Czasami dzieje się tak za sprawą samego dziecka, które chce jeść „to samo” co reszta rodziny. Niemniej zanim reszta rodziny usiądzie na przykład do obiadu, te pierwsze zjadły już kilka posiłków, więc najczęściej towarzyszą tyl- 
ko pozostałym członkom rodziny (i badaczce). Jedzenie pacjentów z niedoborem LCHAD jest nie tylko „inne” od jedzenia spożywanego przez resztę rodziny i/lub rówieśników, charakteryzuje się także innym rytmem czasowym.

Jedzenie co 3-4 godziny (także w nocy, przynajmniej w pierwszych miesiącach i/lub latach życia) stanowi część składową życia z niedoborem LCHAD, jednak drugą stroną medalu jest niejedzenie. W dalszej części tekstu pragnę pokazać, że częstym sposobem na "przezwyciężenie” trudności z jedzeniem jest karmienie przez rurkę i/lub gastrostomia, które same mogą jednak rodzić kolejne problemy.

\section{Karmienie przez rurkę. Biomedyczna odpowiedź na problem niejedzenia}

Spośród dwunastu rodzin pacjentów z niedoborem LCHAD w Polsce, z którymi dotychczas udało nam się porozmawiać, większość chorych w pewnym okresie życia była lub nadal jest karmiona przez rurkę lub gastrostomię. Świadczyły o tym chociażby oprawione $w$ ramki i wiszące na ścianie, stojące na szafkach i umieszczone $\mathrm{w}$ albumach zdjęcia dzieci z sondą. Do przyjrzenia się bliżej kwestii karmienia przez rurkę i PEG-i skłoniły mnie rozmowy z lekarzami w Finlandii, w których za każdym razem powracał motyw gastrostomii. I tak na przykład jedna z fińskich lekarek, pod której opieką znajduje się czworo wciąż niepełnoletnich pacjentów z niedoborem LCHAD, podkreślała, że tak naprawdę nie wiadomo, kiedy „przestać karmić przez rurkę" (miała tu na myśli PEG-a). Wbrew temu, co pojawia się w literaturze naukowej dotyczącej tej choroby, kontynuowała lekarka, problemem w przypadku jej pacjentów nie jest nadwaga, a raczej(nie)jedzenie, a dokładnie nauczenie pacjentów karmionych często od wczesnego wieku przez PEG-a „jak jeść". Czym jest zatem gastrostomia, regularnie określana w rozmowach biomedycznym terminem „PEG”?

W polskiej literaturze biomedycznej gastrostomia jest definiowana na przykład w taki sposób:

Gastrostomia jest rodzajem przetoki żołądkowo-skórnej wytworzonej w celu dostarczania substancji odżywczych bezpośrednio do żołądka. Uzasadnieniem takiego odżywiania jest możliwość żywienia chorych w przypadkach nieoperacyjnych raków przełyku lub po oparzeniach przełyku, często traktowana jest jako zabieg paliatywny w ostatnim okresie życia chorych na raka przełyku, a u dzieci z mukowiscydozą jako możliwość dodatkowego żywienia w godzinach nocnych w celu dostarczenia wymaganego pokrycia energetycznego.(Bazaliński, Barańska 2006). 
Z tego samego tekstu możemy się dowiedzieć, że odbywa się to przez „połączenie światła przewodu pokarmowego ze skórą poprzez wprowadzenie dużej średnicy drenu (15-28 Cha/F) do żołądka przez powłoki brzuszne" (Bazaliński, Barańska 2006). Najczęściej stosowanym sposobem wykonywania przetoki jest obecnie metoda przezskórna endoskopowa (PEG). Tę metodę po raz pierwszy zastosowano w 1979 roku w Stanach Zjednoczonych (Cleveland), gdzie wykonuje się obecnie ponad 220 tysięcy PEG-ów rocznie (Bazaliński, Barańska 2006). Z uwagi na niski odsetek powikłań, metoda gastroskopowa znalazła uznanie w oczach neurologów i onkologów leczących dorosłych. Jak podkreślają lekarze, Dariusz Bazaliński i Beata Barańska (Bazaliński, Barańska 2006) PEG można stosować przez jakiś czas (od miesiąca do kilku miesięcy) lub na stałe. Ponadto, w przeciwieństwie do sondy nosowo-żołądkowej, PEG pozwala na lepszą pielęgnację osoby chorej: „zmniejsza ryzyko zapalenia płuc spowodowanego zachłyśnięciem, zwłaszcza u pacjentów nieprzytomnych, nie powoduje dyskomfortu, stanów zapalnych, odleżyn w jamie nosowej i gardle, istnieje mniejsze ryzyko przypadkowego usunięcia, łatwa w pielęgnacji” (tamże). Jak wskazują doświadczenia pacjentów, o których będę pisała w ostatniej części artykułu, użytkownicy PEG-ów mogą mieć nieco odmienną opinię na temat zarówno „komfortu”, jak i „łatwości pielęgnacji” gastrostomii (por. Pols, Limburg 2016).

Z punktu widzenia biomedycyny, „podstawowym celem odżywiania jest dostarczenie odpowiedniej ilości energii, białka i wody, składników niezbędnych do prawidłowego funkcjonowania organizmu" (Bazaliński, Barańska 2006). Nie ma wątpliwości, że karmienie przez rurkę spełnia tę funkcję. Podejście takie zresztą dobrze wpisuje się w analizy odżywiania podejmowane w ramach krytycznych studiów nad jedzeniem. Podkreślają one znaczenie zmiany w środowisku amerykańskich lekarzy i diabetologów, która nastąpiła po II wojnie światowej, a w szczególności od lat 70. XX wieku (Kimura, Biltekoff, Mudry, Hayes-Conroy 2014). Nie tylko uwaga środowiska lekarskiego przeniosła się z chorób zakaźnych na choroby przewlekłe (np. cukrzycę i choroby układu krążenia), ale również doszło do „dramatycznej ekspansji roli odżywiania i wartości moralnej nadawanej "właściwemu jedzeniu«" (Kimura i in. 2014: 36). Współcześnie rządowe programy informujące o sposobach „właściwego” odżywiania w Stanach Zjednoczonych, jak podkreśla Aya Kimura i in. (Kimura i in. 2014: 37), „zachęcają osoby jedzące, aby traktowały się niczym techników, którzy serwisują swoje ciała [odpowiednią ilością] kalorii i składników odżywczych". Echa takiego podejścia znaleźć można w przytaczanym powyżej cytacie z artykułu polskich 
lekarzy. Co jednak, jeśli - jak wskazują na to studia antropologiczne - jedzenie to coś więcej niż tylko „dostarczanie odpowiedniej ilości energii, białka i wody”, a kwestia budowania i podtrzymywania relacji społeczno-kulturowych? I co, jeśli jedzenia i smaku musimy się „nauczyć” lub starać się go „nie zapomnieć”, jak ma to właśnie miejsce w wypadku pacjentów karmionych przez rurkę?

\section{Nie(naturalność) jedzenia: pokarmy, których musimy się nauczyć}

W ostatnich latach ukazało się kilka prac, głównie holenderskich i duńskich badaczek społecznych, analizujących doświadczenia pacjentów, którzy są lub byli karmieni przez rurkę i na nowo "uczą się" jedzenia i/lub smakowania potraw (Hillersdal, Christensen, Holm 2017; Mol 2011; Pols, Limburg 2016). Jakkolwiek porównawczo cenne, badania te skupiały się na doświadczeniach chorych w zaawansowanym stadium (i wieku), cierpiących na stwardnienie zanikowe boczne, rzadką chorobę neurozwyrodnieniową. Decydowali się oni na PEG-a zwykle w momencie, kiedy nie byli w stanie przełykać (Pols, Limburg 2016) i/lub mieli problemy z przełykaniem pokarmów i napojów w wyniku problemów neurologicznych lub wylewu (Mol 2011). Nie traktowały natomiast o doświadczeniach chorych dzieci i młodzieży, którzy od urodzenia cierpią na choroby rzadkie.

Kiedy rozmawiałam (MR - autorka tekstu) z dietetyczką (D) pracującą $\mathrm{w}$ dużym centrum zdrowia, pod opieką którego, jak mi powiedziano, jest obecnie około dwudziestu pacjentów z niedoborem LCHAD, o tym, ilu spośród nich ma założone PEG-i, zaznaczyła, że „to zdecydowanie nie jest norma” i dodała: „To taka troszeczkę ostateczność. Zresztą rodzice też tak to traktują, jak ostateczność. Rodzice zawsze walczą o to jednak, żeby gdzieś tam rozkarmiać dziecko innymi sposobami. Boją się" (zob. Pols, Limburg 2016: 365). Na moje pytanie o to, z czego mogą wynikać te obawy, odpowiedziała:

D: Wiadomo, że jest większe ryzyko zakażeń. Chociażby tego się boją. Może się boją samej opieki nad tym i tego, że dziecko będzie miało kontakt zewnętrzny ze środowiskiem przez brzuch, co nie jest jakąś tam normą. Może to też w pewnym sensie stygmatyzuje, tak. Myślę, że tam różne mogą być obawy.

MR: No bo ja to sobie tak pomyślałam, że z drugiej strony może byliby zadowoleni, no że tak w pewnym sensie łatwo i mają kontrolę, więc nie ma...

D: No, powiem szczerze, że niektórzy, przy tych innych chorobach, wrodzonych wadach metabolizmu, dzieci, które musiały mieć założone PEG-i, no to rodzice już fak- 
tycznie tak troszeczkę za dużo bazują na tych PEG-ach zamiast np. uczyć dziecko i przyzwyczajać do tego jedzenia doustnego.

MR: Czyli dziecko właściwie mogłoby, jeśli jest na PEG-u od niemowlęcia, mogłoby właściwie nie jeść, rozumiem?

D: Teoretycznie tak, natomiast staramy się stymulować dziecko do jedzenia, jeżeli, tak jak mówiłam, jest to możliwe.

Wy powiedź dietetyczki dobrze obrazuje ambiwalentną pozycję, jaką gastrostomia lub generalnie technologie biomedyczne zajmują z perspektywy użytkowników i ich opiekunów. Właściwym czy „normalnym” sposobem jedzenia nie jest podawanie go przez, jak to określi przywoływana w dalszej części tego artykułu pacjentka, „dziurę w brzuchu”, a jedzenie przez usta. Ten pierwszy sposób „jedzenia” nie tylko budzi obawy natury medycznej i higienicznej (obawy przed zakażeniem, pytania o właściwy sposób pielęgnacji itd.), ale z uwagi na swoją „widoczność” może również stygmatyzować społecznie. Jednocześnie kiedy technologia biomedyczna stała się już częścią życia pacjenta i jego bliskich, okazuje się, że może ona usprawnić ich codzienne funkcjonowanie w niespodziewany dotąd sposób. Do tego nawet stopnia, że staje się "naturalna” i z uwagi na swoją większą „skuteczność” zastępuje - całkowicie lub w dużej mierze - sposób jedzenia „przez usta” (zob. Rabinow 1996). Jak mówi dietetyczka: „zamiast np. uczyć dziecko i przyzwyczajać do tego jedzenia doustnego” rodzice „bazują na tych PEG-ach”.

Dobrym przykładem na sytuację, kiedy to odżywianie zapośredniczone przez technologię biomedyczną stało się naturalnym sposobem spożywania posiłków jest historia jednej z pacjentek mojej rozmówczyni. Jest to dziewczynka z niedoborem LCHAD, u której założono gastrostomię w wieku niemowlęcym (przed ukończeniem pierwszego roku życia). Dziewczynka chodzi obecnie do przedszkola, ale rodzice nadal karmią ją przez PEG-a:

Rodzice jej głównie podają posiłki do PEG-a, natomiast też je troszeczkę doustnie. No bo, jeżeli mimo wszystko jest zachowana ta możliwość, czyli jest zachowana ciągłość układu pokarmowego, dziecko przełyka, a jest to tylko, nie wiem, niechęć do jedzenia, jakieś problemy psychologiczne, no to staramy się tą dietę rozszerzać, żeby jednak... no OK ten PEG, początkowo, podstawa, ale później, żeby jakoś tak bazować na tych posiłkach doustnych.

Decyzję o karmieniu przez sondę nosowo-żołądkową, według tej samej rozmówczyni, w przypadku innej dziewczynki podjęto, ponieważ „po prostu dziecko nie 
jadło". To właśnie kwestia (nie)jedzenia zdaje się odgrywać kluczową rolę w podjęciu decyzji o karmieniu przez rurkę. Co więcej, życie codzienne większości dzieci i nastolatków z niedoborem LCHAD w Polsce zdaje się oscylować między okresami „normalnego” (oczywiście dla tej choroby) jedzenia a okresami niejedzenia, które niejed nokrotnie zostają zapośredniczone przez biotechnologię medyczną w postaci sondy nosowo-żołądkowej lub rzadziej PEG-a.

Tak było w przypadku uczęszczającej obecnie do szkoły ponadpodstawowej nastolatki, Kamili, z którą z racji wieku mogłam swobodnie porozmawiać o jej doświadczeniach $\mathrm{z}$ jedzeniem przez rurkę (w rodzinach, $\mathrm{z}$ którymi udało nam się dotychczas porozmawiać, większość dzieci z niedoborem LCHAD jest w wieku przedszkolnym lub wczesnoszkolnym). W rozmowie uczestniczyła również mama Kamili, pani Katarzyna (PK).

Jeśli chodzi o jedzenie, przez pierwsze miesiące życia Kamila zapowiadała się bardzo dobrze - jadła regularnie, co napawało optymizmem nie tylko jej matkę, ale i lekarzy prowadzących. Według pani Katarzyny: „Pani doktor była bardzo zadowolona, że ona je. Bo te dzieci nie chcą jeść. Bo to jest tak: co trzy godziny, bez przerw nocnych, jedzenie. Nie chcą jeść, ona mówi, z jedzeniem to jest koszmar". Po powrocie ze szpitala jednak Kamila „przestała jeść”, „buzię zamknęła i koniec. Nie będzie jadła”. Pani Katarzyna określiła to krótko: „był kryzys z jedzeniem. Był. Był kryzys". Chociaż sonda "rozwiązała” problem z niejedzeniem, to nie była idealnym rozwiązaniem. Kamila miała „wiecznie katar, non stop podrażnione, wiecznie katar", a "policzki od plastra wiecznie zaognione”.

Kamila, jak powiedziała pani Katarzyna, „bardzo często mi wpadała w dekompensacje [...]. Ona mi tak: często wymiotowała, biegunek nie, ale wymioty częste. Ale u niej wystarczyło, że zwymiotowała raz i już miała podniesione enzymy mięśniowe. U niej bardzo szybko dekompensacja. Nawet to jest do dzisiaj”. Po czym zaraz dodała: „To już wiedziałam, że już do szpitala muszę na kroplówki”.

Problemy z jedzeniem, częste dekompensacje i wizyty w szpitalu, podczas których Kamili, jak i innym pacjentom cierpiącym na tę chorobę, podawano roztwór glukozy, sprawiły, że kilka lat temu jej matka podjęła decyzję o tym, że jedynym rozwiązaniem w tej sytuacji będzie PEG:

PK: I wtedy padło, żeby założyć PEG-a, bo nie było innego wyjścia.

MR: Jak to było? 
PK: Ja się na PEG-a zgodziłam w sumie od razu, bo przemyślałam sprawę. A zresztą nawet $\mathrm{z}$ dr X dyskutowałam na temat PEG-a dzień wcześniej. I mówię: to jest bez sensu tak trzymać ją w szpitalu miesiącami. Mówię: ona mi nie będzie jadła, ja pojadę do domu, będzie problem. Mówię znowu będą dekompensacje, wieczne kłucia. Mówię coś trzeba, na sondę ona już się nie zgodzi, bo ona jest już za duża na sondę. Mówię trzeba będzie założyć PEG-a. [...]

MR: Kto w ogóle pani zaproponował, żeby [założyć] tego PEG-a?

PK: Ja sobie poczytałam. Powiem tak: ja sobie sama poczytałam, porozmawiałam z dwoma mamami, które mają PEG-a. Powiedziały mi za i przeciw. [...] I później pani doktor, że zakładają tego PEG-a, bo nie ma innego wyjścia, bo tak to by musiała mieszkać w szpitalu.

Lekarze w centrum zdrowia zgodzili się ostatecznie z decyzją matki i Kamila przez ponad dwa lata karmiona była przez gastrostomię odżywczą typu „grzybek”. Kiedy zapytałam, jak „obsługuje się” PEG-a, pani Katarzyna powiedziała, że to proste: „To jest tak: strzykawkę ma się z jedzeniem, guzik się otwiera, podłącza się rurkę no i strzykawką się podaje. I to tam, to tam żadna filozofia. Ona mogłaby sama, ale ona nie robiła”. Zaletą PEG-a było też to, że Kamila mogła być karmiona Humaną z MCT także w nocy bez budzenia: „Ona se mogła spać i ja jej podałam”.

O PEG-u i „grzybku”, szczególnie o momentach, kiedy dochodziło do ich wymiany w szpitalu, Kamila mówiła jako o „dziurze w brzuchu”. Kiedy zapytałam się o to, jak się czuła „z dziurą w brzuchu?”, odpowiedziała: „To było dziwne, bo jak ci ktoś w środku, w brzuchu coś wyciąga albo wkłada, to jest strasznie dziwne uczucie". Decyzję o wyjęciu PEG-a podjęła sama Kamila, której przeszkadzał fakt, że nie dało się go zbyt dobrze ukryć pod ubraniem (por. Pols, Limburg 2016: 374) oraz konieczność nieustannego oczyszczania, odkażania i generalnie utrzymywania „grzybka” w stanie „suchości”. Wymienione przez moją rozmówczynię powody potwierdzają poniekąd obawy rodziców przed założeniem PEG-a, które pojawiły się w przytaczanej wcześniej wypowiedzi dietetyczki. W przypadku Kamili dodatkowo zmienił się jej stosunek do jedzenia:

No, ja właśnie wtedy miałam te problemy z tym jedzeniem, to bułki z ketchupem, co warzyw za bardzo nie chciałam jeść i takich rzeczy [...] to spaghetti, zupę pomidorową [...] Ja nie jem tłustych rzeczy, więc ja jak coś ma posmak taki albo czuję na ustach albo na palcach coś tłustego, to ja wiem, że to jest tłuste. [...] I wiadomo, że jakbym miała jeść tak co dwie godziny, co trzy, to się potem człowiekowi nie chce. I nie dziwię się, że

${ }^{6}$ Wykorzystuję słownictwo, którym posługują się użytkownicy i/lub ich rodziny. „Grzybek” to znajdujący się na powierzchni brzucha "guzik”, do którego na czas karmienia podłącza się rurkę. 
kiedyś się tak wkurzałam, bo się tak naprawdę nie da, jak musiałam tyle jeść, szczególnie jak byłam młodsza. No, teraz to wiem, że muszę jeść, więc jem... Pilnować, zawsze sama się pilnuję. Wiem, co mogę jeść, czego nie mogę, więc nikt mi nie musi mówić tego. A z czasem tego jedzenia to też wiedziałam, bo wiadomo, że nie chcę leżeć w szpitalu, bo to jest strasznie męczące i te kroplówki. I to nie miałoby sensu, gdybym nie jadła, bo byłoby jeszcze gorzej.

Wypowiedź Kamili wskazuje na dwie istotne kwestie, które stanowią część składową życia codziennego z rzadką chorobą metaboliczną. Po pierwsze, na wspomnianą już kilkakrotnie w niniejszym artykule konieczność częstego spożywania posiłków przez osoby z deficytem LCHAD, która wykracza poza „normalną” częstotliwość jedzenia i sprawia, że „potem człowiekowi nie chce [się jeść].[...] Bo się tak naprawdę nie da, jak musiałam tyle jeść". Po drugie, na to, że podobnie jak i inne osoby cierpiące na tę chorobę Kamila nie może sobie pozwolić na „niejedzenie” i „musi” nauczyć się (często) jeść. W przeciwnym razie „byłoby jeszcze gorzej”, a więc czekałyby ją częste hospitalizacje. Doświadczeniom częstego pobytu w szpitalu oraz wiedzy, początkowo wpajanej przez rodziców (i lekarzy) o tym, co można jeść towarzyszy monitorowanie tego, co się je i jak często się je.

W trakcie kilkuletniego „epizodu” z PEG-iem Kamila wciąż „normalnie” piła herbatę czy jadła swoją ulubioną zupę pomidorową. Niemniej, jak przyznała, życie z PEG-iem nadaje innego znaczenia kwestii smaku: „Ale to już się smaku nie czuje, ani w ogóle. Ale jak coś się niby podaje, wodę, jak przepłukiwać, to tutaj czułam jakbym połykała wodę i tutaj podchodził mi smak jakby". Jako że w życiu Kamili doświadczenia $\mathrm{z}$ biotechnologią medyczną taką jak PEG i sonda nosowo-żołądkowa były okresowe, nawet wówczas nie opuszczała jej pamięć smaku i jedzenia (zob. Mol 2011: 472; Hillersdal i in. 2017: 482-483). Jednakże wśród matek, które pani Katarzyna pytała o poradę w sprawie PEG-a, były i takie, których dzieci miały założonego PEG-a niemal od urodzenia i - jak zgodnie przyznawały przywoływane w tym tekście przedstawicielki służby zdrowia w Finlandii i w Polsce - nie umiały (już) jeść. Jednemu z takich chłopców, według Pani Katarzyny, „już się nie chce buzią jeść", „nie jest nauczony jeść”. Odżywiany jedynie przez PEG-a chłopiec stał się zależny od rurki i matki, która go karmi. Taka zależność, zdaniem mojej rozmówczyni, odbiega od normalności i czyni z chłopca kalekę: „I to jest właśnie niedobre, bo jak możesz jeść buzią, to jedz buzią". Podobnie do opisywanej wcześniej przez dietetyczkę dziewczynki, której rodzice „głównie podają posiłki do PEG-a”, także dla tego chłopca karmienie zapośredniczone przez technologię biomedyczną stało się 
naturalnym sposobem odżywiania. Parafrazując Hilldersdal i in., które analizowały to, jak zmieniało się doświadczenie jedzenia, nasycenia i głodu u skrajnie otyłych pacjentów, którzy poddali się leczeniu bariatrycznemu, technologie biomedyczne „zmieniają ciało w sposób, który zmusza pacjentów do zmiany swoich nawyków żywieniowych" (2017: 485). W pewnych wypadkach taka zmiana może być na tyle radykalna, że czyni z jedzenia - tutaj jedzenia przez usta - coś „nienaturalnego”.

\section{Podsumowanie}

Jak podkreślają antropolodzy medyczni, Peter Brown i Ron Barrett, rozwój nowych technologii biomedycznych umożliwił:

przesunięcie granic życia; zarówno jeśli chodzi o umożliwienie kontynuacji życia małych, urodzonych przedwcześnie noworodków (które w przeszłości czekałaby śmierć), jak i odsuwanie śmierci (za sprawą respiratorów i sond do karmienia) na niesłychanie długi czas. Krótko mówiąc, technologie biomedyczne wymagają nowej definicji życia i śmierci (Brown, Barrett 2010: 209).

Wynalezienie i zastosowanie sond do karmienia i gastrostomii można jak najbardziej zaliczyć do - jak napisano na stronach Feeding Tube Awareness Foundation - „interwencji medycznych ratujących życie”. Jednak powiązanie karmienia przez rurkę - także w powyższym cytacie z poczytnego tomu przygotowanego z myślą o studentach antropologii medycznej - przede wszystkim z „odsuwaniem śmierci” zamazuje cały szereg znaczeń, z którymi wiąże się jej stosowanie dla chorych na rzadkie przypadłości, w tym pacjentów z niedoborem LCHAD i ich rodzin. Chodzi tu nie tylko o - usankcjonowane biomedycznie - dostarczanie ciału chorego składników odżywczych, ale również o obawy i nadzieje, jakie wiążą się z tą technologią biomedyczną oraz codzienną praktykę, aż wreszcie „skutki” takiego sposobu przyjmowania pożywienia, w tym odczucia smaku i kwestia „umiejętności” jedzenia. Równie istotne jest to, że odżywianie przez rurkę - a nie przez usta - może stać się w niektórych wypadkach „naturalnym” sposobem jedzenia/karmienia, prowadząc tym samym do pytań natury antropologicznej i filozoficznej o to, czy jedzenie jest czynnością „naturalną”, na czym w ogóle polega, i czym jest jedzenie „naturalne”. Jak podkreślają Jeannette Pols i Sarah Limburg, rurka do karmienia ma „różne tożsamości” (Pols, Limburg 2016: 375) i „nie funkcjonuje sama "przez się« [...]. Otrzymuje ostatecznie swoją tożsamość w trakcie okoliczności, w których się jej używa, niektóre rzeczy umożliwiając, a inne utrudniając” (Pols, Limburg 
2016: 373). Chociaż zatem karmienie przez rurkę i gastrostomia są niejednokrotnie niezbędne, by pacjenci przeżyli, jednak ich zastosowanie prowadzi do dalszych pytań o to, czym jest jedzenie, czy można się go nauczyć albo zapomnieć. Na podstawie wciąż kontynuowanych badań prowadzonych z pacjentami z niedoborem LCHAD, ich rodzicami i lekarzami, w niniejszym artykule starałam się wykroczyć zarówno poza biomedyczne definicje karmienia przez rurkę jako technologii umożliwiającej „dostarczanie substancji odżywczych bezpośrednio do żołądka" (Bazaliński, Barańska 2006), jak i utożsamianie jej z „przesuwaniem granic życia” przede wszystkim w przypadku osób starszych i umierających.

\section{Podziękowania}

Chciałabym podziękować badaczkom biorącym udział w niniejszym projekcie: $\mathrm{dr}$ hab. Annie Kwaśniewskiej, prof. UG oraz mgr Annie Chowaniec-Rylke, doktorantce na UW. Szczególnie dziękuję wszystkim osobom, które zgodziły się wziąć udział $\mathrm{w}$ badaniach: dzieciom, nastolatkom i dorosłym z niedoborem LCHAD i ich rodzinom, lekarzom, dietetykom i genetykom oraz przedstawicielom stowarzyszeń w Finlandii i w Polsce. Dziękuję również redakcji czasopisma „Lud”, w szczególności dr hab. Agnieszce Kościańskiej oraz anonimowym recenzentom za cenne wskazówki odnośnie do pierwszej wersji artykułu.

\section{Bibliografia}

Allison, A. (2007). Japońskie matki i obentō: pudełko z drugim śniadaniem jako ideologiczny aparat państwa (przeł. A. Ostolski). W: R.E. Hryciuk, A. Kościańska (red.), Gender. Perspektywa antropologiczna. T. 1: Organizacja społeczna, (ss. 146-170). Warszawa: Wydawnictwo Uniwersytetu Warszawskiego.

Bazaliński, D., Barańska, B. (2006). Opieka nad pacjentem z gastrostomia odżywczą. Medycyna Rodzinna, 2. Pozyskano z http://www.czytelniamedyczna.pl/440,opieka-nad-pacjentem-z-gastrostomia-odzywcza.html.

Bishop, J.P. (2011). The Sovereign Subject and Death. W: Idem. The anticipatory corpse. Medicine, Power, and the Care of the Dying, 197-223. Notre Dame: University of Notre Dame Press. Boylson, T. (2013). Food, Life, and Material religion in Ethiopian Orthodox Christianity. W: J. Boddy, M. Lambek (red.), A Companion to the Anthropology of Religion, 257-273. Malden: Wiley Blackwell. 
Brown, P., Barrett, J.R. (2010). Understanding and Applying Medical Anthropology. New York: McGraw-Hill.

Douglas, M. (2007 [1966]). Czystość i zmaza. Analiza pojęć nieczystości i tabu (przeł. M. Bucholc). Warszawa: Państwowy Instytut Wydawniczy.

Feeding Tube Awareness Foundation (b.d.). Pozyskano z http://www.feedingtubeawareness. org/about-us/mission-purpose/.

Food for Thought (b.d.). The official blog of the American Society for Parenteral and Enteral Nutrition (A.S.P.E.N.). Pozyskano z http://blog.nutritioncare.org/its-tube-feeding-awareness-week/.

Gibbon, S., Novas, C. (2008). Introduction: biosocialities, genetics and the social sciences. In: S. Gibbon and C. Novas (red.), Biosocialities, Genetics and the Social Sciences. Making biologies and identities, 1-19. London \& New York: Routledge.

Gick, J. (b.d.) Acydurie organiczne. Przewodnik dla pacjentów, rodziców i rodzin. European Registry and Network for Intoxication Type Metabolic Diseases. Pozyskano z http://www.e-imd.org/ rc/e-imd/htm/Article/2011/e-imd-20110729-235456-354/src/htm_fullText/pl/aciduries_org_POL.pdf.

Helman, C.G. (2007). Culture, Health and Illness. Boca Raton: CRC Press. Taylor \& Francis Group.

Hillersdal, L., Christensen, B.J., Holm, L. (2017). Changing tastes: learning hunger and fullness after gastric bypass surgery. Sociology of Health \& Illness, 39 (3), 474-487; doi:10.1111/14679566.12504

Huyard, C. (2009). How did uncommon disorders become 'rare diseases'? History of a boundary object. Sociology of Health \& Illness, 31 (4), 463-477; doi:10.1111/j.1467-9566.2008.01143.x

Immonen, T. (2016). Long-chain 3-hydroxyacyl-CoA dehydrogenase deficiency in Finland - earlier diagnosis and strict diets improve the survival rate and clinical course. PhD Manuscript. Helsinki: Helsinki University Hospital, University of Helsinki.

Kimura, A.H., Biltekoff, Ch., Mudry, J., Hayes-Conroy, J. (2014). Nutrition as Project. Gastronomica. The Journal of Critical Food Studies, 14 (3), 34-45; doi:10.1525/gfc.2014.14.3.34

Landecker, H. (2013). Postindustrial Metabolism: Fat Knowledge. Public Culture, 25 (3), 495-522; doi:10.1215/08992363-2144625

Larotonda, A. (2016). Experiencing Rare Diseases. W: L. Manderson, E. Cartwright, A. Hardon (red.), The Routledge Handbook of Medical Anthropology (ss. 26-30). New York, London: Routledge. 
Libura, M., Władusiuk, M., Małowicka,M., Grabowska,E., Gałązka-Sobotka, M., Gryglewicz, J. (2016). Choroby rzadkie w Polsce. Stan obecny i prespektywy. Warszawa: Uczelnia Łazarskiego.

Mauss, M. (2001 [1936]). Sposoby posługiwania się ciałem. W: Idem, Socjologia i antropologia (ss. 391--425). Warszawa: Wydawnictwo KR.

Mintz, S.W. (1985). Sweetness and Power. The Place of Sugar in Modern History. New York: Penguin Books.

Mol, A. (2011). Tasting Food. Tasting Between the Laboratory and the Clinic. W: F. E. Mascia-Lees (red.), A Companion to the Anthropology of the Body and Embodiment (ss. 467-480). Oxford: Wiley-Blackwell.

Paul, D.B., Brosco, J.P. (2013). The PKU Paradox. A Short History of Genetic Disease. Baltimore: Johns Hopkins University Press.

Piekutowska-Abramczuk, D. i in. (2010). A comprehensive HADHA c.1528G $>$ C frequency study reveals high prevalence of long-chain 3-hydroxyacyl-CoA dehydrogenase deficiency in Poland. J Inherit Metab Dis, 33 (3), (ss. 373-377); doi:10.1007/s10545-010-9190-7

Pols, J., Limburg, S. (2016). A Matter of Taste? Quality of Life in Day-to-Day Living with ALS and a Feeding Tube. Culture, Medicine, and Psychiatry, 40, (ss. 361-382); doi:10.1007/s11013-015-9479-y

Rabinow, P. (1996). Artificiality and Enlightenment: From Sociobiology to Biosociality. W: Idem, Essays on the Anthropology of Reason (ss. 91-111). Princeton: Princeton University Press.

Sykut-Cegielska, J.(2006). Mitochondrialne zaburzenia utleniania kwasów tłuszczowych. Badania kliniczne, biochemiczne i molekularne u polskich pacjentów. Manuskrypt pracy habilitacyjnej. Warszawa: Instytut „Pomnik-Centrum Zdrowia Dziecka”.

Sykut-Cegielska, J. i in. (2011). Urgent metabolic service improves survival in long-chain 3-hydroxyacyl-CoA dehydrogenase (LCHAD) deficiency detected by symptomatic identification and pilot newborn screening. J Inherit Metab Dis, 34 (1), 185-195; doi:10.1007/s10545-010-9244-x

Timmermans, S., Buchbinder, M. (2013). Saving Babies? The Consequences of Newborn Genetic Screening. Chicago, London: The University of Chicago Press.

Weker, H., Barańska, M. (red). (2014). Żywienie niemowląt i małych dzieci. Zasady postępowania w żywieniu zbiorowym. Warszawa: Instytut Matki i Dziecka i Główny Inspektor Sanitarny. Pozyskano z http://www.imid.med.pl/images/do-pobrania/Zywienie_niemowlat _www.pdf. 